\title{
Suomenruotsalaisuusliike suomalaisuusliikkeen peilikuvana
}

Max Engman: Kielikysymys. Suomenruotsalaisuuden synty 1812-1922. Suomen ruotsalainen historia 3. Suomentanut Kari Koski. Svenska litteratursällskapet i Finland. Helsinki 2018. 483 s. ISBN 978-951583-425-6.

Max Engmanin vuonna 2016 ruotsiksi ilmestyneestä Språkfrågan-teoksesta julkaistiin viime vuonna suomennos. Kirjan aihe on ajankohtainen, ja teos avaa uusia näkökulmia myös suomalaisuusliikkeen vaiheisiin. Kyseessä on melkoinen järkäle sekä laajuudeltaan että varsinkin sisällöltään. Vaikka alaotsikon mukaan teoksen aiheena on suomenruotsalaisuuden synty 1812-1922, lukija huomaa nopeasti, että noin kolmasosa kirjasta käsitteleekin suomalaisuusliikkeen historiaa lähtien Turun romantikoista ja päätyen lopulta 1900-luvun taitteen vanha- ja nuorsuomalaisiin.

Koko suomenruotsalaisuusliikkeen synty onkin ollut seurausta sitä edeltäneestä suomalaisuusliikkeestä. Käytännössä ne ovat kietoutuneet monella tavoin toisiinsa. Ne ovat myös olleet melkein toistensa peilikuvia. Niiden välinen aikaero oli kuitenkin noin viisikymmentä vuotta, mitä havainnollistaa esimerkiksi se, että Suomalaisen Kirjallisuuden Seura perustettiin vuonna 1831 ja Svenska litteratursällskapet i Finland Runebergin päivänä vuonna 1885 .

Teoksen ajoitus lähtee siitä, että vuonna 1812 Suomi sai ne rajat, jotka sillä oli koko autonomian ajan. Vuoteen 1922 mennessä Suomessa oli puolestaan vahvistettu uusi valtiosääntö ja kielilainsäädäntö. Myös ruotsalaisten kulttuuriautonomia oli saanut muotonsa ja Ahvenanmaan sekä Itä-Karjalan kysymykset oli ratkaistu.
Näin mittavaa teosta voi esitellä vain valikoiden. Otan ensin puheeksi Suomen uuden tilanteen vuonna 1809 , sitten suomalaiskansallisen liikkeen vaiheet, sen jälkeen suomenruotsalaisuuden synnyn sekä lopuksi suomenruotsalaisuusliikkeen poliittisena toimijana.

Teoksen kirjoittaja Max Engman (s. 1945) on Åbo Akademin yleisen historian emeritusprofessori. Hän on tutkimuksissaan käsitellyt Suomea Venäjän keisarikunnan osana ja suomalaisia autonomian aikana Venäjällä, varsinkin Pietarissa. Hän toimi myös pitkään Historisk Tidskrift för Finland -aikakauskirjan vastaavana toimittajana.

\section{Suomi 1809}

Teoksen alkuluvuissa, "Ruotsalaisesta Suomesta uuteen Suomeen" (s. 27-62) ja "Etääntyminen Ruotsista" (s. 63-96), lähtökohtana on Suomen uusi tilanne vuoden 1809 jälkeen. Silloin Suomen yhteys vanhaan emämaahan, Ruotsiin, oli katkennut, ja siitä oli tullut osa keisarikuntaa, joka ulottui Oolannista Sitkaan. Myös suomen ja ruotsin kielisuhteet muuttuivat radikaalisti. Ennen vuotta 1809 Ruotsin valtakunnassa suomenkielisten osuus oli noin $22 \%$, kun taas uudessa suuriruhtinaskunnassa suomea puhui äidinkielenään noin $87 \%$. Toisaalta muutos ei ollut käytännössä niin radikaali kuin näistä luvuista voisi päätellä, sillä Suomen valtaapitävistä säätyläisistä lähes kaikki puhuivat pääkielenään ruotsia aina 1860-1870-luvuille asti.

Suomalaiset joutuivat kuitenkin selvittämään suhteitaan niin vanhaan emämaahan kuin uuteen isäntään, Venäjän keisarikuntaan, johon Suomi oli liitetty Porvoon valtiopäivillä 1809. Irtautuminen Ruotsista antoi Suomelle uutta liik- 
kumavaraa, ja toisaalta kaiken perustana säilyi Ruotsin aikainen vuoden 1743 laki, jonka merkitystä Engmanin sanoin "on vaikea yliarvioida" (s. 39). Suomella oli oma keskushallinto, ja suhteita Venäjään suomalaiset hoitivat ministerivaltiosihteerin kautta suoraan Pietarissa keisarin kanssa. Niinpä Suomi onnistui tasapainoilemaan melko itsenäisesti aina 1880-luvulle saakka, jolloin Aleksanteri III teki selväksi, ettei autonomiaa enää laajenneta (s. 40-41).

Engman luo jännitteitä kirjaan viittaamalla siihen, että suomalaisilla oli usein monia erilaisia vaihtoehtoja. Esimerkiksi heti valittaessa nuoren suuriruhtinaskunnan pääkaupunkia 1809 ja 1812 (s. $52-$ 57) tarjolla oli kolme vaihtoehtoa: Suomen vanha alueellinen keskus Turku sekä Hämeenlinna ja Helsinki. Mahdollista olisi ollut sekin, ettei Suomi olisi saanut lainkaan omaa pääkaupunkia vaan sitä olisi hallittu suoraan Pietarista, samaan tapaan kuin Ruotsin vallan aikana Tukholmasta. Suomi sai kuitenkin oman pääkaupungin, johon maan hallinto keskitettiin. Vuonna 1809 Hämeenlinna oli ollut vähän aikaa käytännössä pääkaupungin asemassa. Turkua tukivat varsinkin historialliset syyt. Venäläisten mielestä se oli kuitenkin liian lähellä Ruotsia, ja Helsingissä oli myös Viapori. Kaupunki oli kaiken lisäksi palanut 1808, joten siitä voitiin rakentaa uusi, uljas pääkaupunki. Niinpä keisari antoi vuonna 1812 määräyksen, jonka mukaan Helsingistä tuli Suomen pääkaupunki.

\section{Suomalaiskansallinen liike - fennomaanit}

Luvussa "Suomen kolme kieltä" (s. 97142) tulee pöydälle jälleen kolme vaihtoehtoa. Tällä kertaa on kyse suuriruhtinaskunnan kielistä, joita oli kolme: suomi, ruotsi ja venäjä. Näistä venäjä oli suuren keisarikunnan pääkieli. Ruotsi oli ennen muuta Suomen hallitsevan luokan, sääty- läisten, kieli, ja sitä oli käytetty jo aiemmin hallintokielenä. Suomi oli ylivoimainen enemmistökieli, mutta sen sosiaalinen asema oli alhainen.

Suomen- ja ruotsinkieliset sekä venäläiset pelasivat näillä korteilla koko autonomian ajan toisiaan vastaan. Kuviona oli yleensä se, että kahta korttia käytettiin kolmatta vastaan. Vuoden 1809 jälkeen venäjää pyrittiin käyttämään jonkin verran hallinnossa, mutta se joutui väistymään ruotsin tieltä (s. 99-101). Merkittävä muutos tapahtui vasta vuoden 1900 kielimanifestin jälkeen, jolloin venäjän ja suomen käyttöä hallintokielinä lisättiin (s. 135-137).

Ruotsi säilytti kuitenkin pitkään johtavan aseman Suomen hallinto- ja kulttuurikielenä, ja Engmanin mukaan sen asema jopa vahvistui siihen saakka, kunnes kielitaistelu kiihtyi ja suomen kieli löi itsensä läpi laajalla rintamalla (s. 101-102). Suomi oli puolestaan pitkään näiden kolmen kielen hierarkiassa alimpana, sillä sen puhujat kuuluivat oppimattomaan rahvaaseen. Jos joku heidän joukostaan lähti opintielle ja kohosi säätyläisten joukkoon, hintana oli koulun käyminen ruotsiksi ja kielen vaihtaminen.

180o-luvun kuluessa suomen kielen asema kuitenkin muuttui ratkaisevasti suomalaisuusliikkeen ansiosta. Liikkeen keskeiset kehitysvaiheet voidaan ajoittaa 1820-luvulle, 1840-luvulle ja 1870-luvulle (s. 79).

1820-luku oli Turun romantikkojen aikaa. Heistä merkittävimpiä olivat A. I. Arvidsson, E. G. Ehrström ja J. G. Linsén. He lähtivät etsimään Suomen uutta kulttuurista identiteettiä suomen kielestä ja suomalaisesta kansanperinteestä (s. 84-85). Lehtikirjoituksissaan he nostivat esiin ajatuksen, jonka mukaan suomi oli ruotsinkielisen sivistyneistön "oikea" tai "varsinainen" äidinkieli (s. 156-159). He eivät itse kuitenkaan vaihtaneet kieltään. Tämän vaiheen huipentumana voi pitää Elias Lönnrotin Kalevalan ensi version ilmestymistä vuonna 1835. Samalla Suomen sisäosat ja 
Itä-Suomi löydettiin "kansanrunouden ja kauniin suomen syntysijoina" (s. 77).

Fennomaanien ensimmäistä polvea edustivat J. V. Snellmanin johtamat kulttuurifennomaanit. Snellmanin ohjelma oli radikaali: suomen kieli tuli nostaa valtakunnan pääkieleksi niin hallinnossa kuin yhteiskunnan ja kulttuurielämänkin alueilla. Koska suomenkielistä sivistyneistöä ei ollut, ruotsinkielisten säätyläisten tuli ensi vaiheessa vaihtaa kielensä ruotsista suomeksi. Seuraavassa vaiheessa tuli kouluttaa suomalaisesta rahvaasta jo äidinkielenään suomea puhuvaa sivistyneistöä. Keskeinen tehtävä tulisi olemaan suomenkielisellä koululaitoksella. On sinänsä kiintoisaa, että aikansa edistynein suomenkielinen poikakoulu perustettiin Pietariin 1844 ja tyttökoulu 1849, kun Suomessa ensimmäinen suomenkielinen oppikoulu aloitti toimintansa Jyväskylässä 1858 (s. 59, 118).

Snellmanin ohjelman ehtona oli suomen kielen kehittäminen eurooppalaiseksi kulttuurikieleksi, jolla voidaan kirjoittaa omakielistä kirjallisuutta. Tämä oli muutenkin suomalaisuusliikkeen suurimpia urakoita $1800-l u v u l l a$. Siihen kuului vierasperäisten sanojen ja ilmausten korvaaminen suomalaisilla, joko murteista saatavilla tai tavallisimmin uudissanoilla. Tähän työhön oli ryhdytty jo 1830-luvulla.

Vaikka Engman on käsitellyt perusteellisesti Snellmanin kulttuurifennomaniaa, hän ei ole puuttunut lainkaan Snellmanin ja suomen kielen ohjailijoiden näkemyseroihin suomen kielen kehittämisperiaatteista. Snellmanin lähtökohtana oli, että parasta kieltä oli proosakirjallisuuden kieli (Snellman 1845). Oikeakielisyysmiesten näkemyksiä hän ei sitä vastoin arvostanut. Syitä oli ainakin kolme. Ensinnäkin hän piti liiallista purismia haitallisena, sillä vaarana oli, että suomen kieli etääntyisi liikaa muista eurooppalaisista kulttuurikielistä. Toiseksi hän vierasti itäsuomalaisten sanojen tuomista "muutamista Raja-Karjalan pitäjistä" kirjakieleen. Hänen mukaansa pa- rempi vaihtoehto oli kehittää suomea siltä pohjalta, miksi se oli muotoutunut monen vuosisadan aikana. (Snellman 1848.)

Kolmanneksi hän oli erityisen ärtynyt Lönnrotin vuonna 1845 julkaisemasta kirjoituksesta Muukalaisuudesta Suomessa, jossa Lönnrot vierassanojen lisäksi vastusti kieliopillisia muukalaisuuksia. Niillä hän tarkoitti analyyttisten ilmausten suosimista suomelle ominaisten synteettisten sijaan, esim. ilman huonetta, rantaa myöten pro huoneetta, rannatse. Lönnrot puuttui myös pronominien liikakäyttöön sellaisissa tapauksissa, joissa persoonapäätteet tai omistusliitteet jo osoittivat, mistä on kyse, esim. luin jo kirjani. Snellman kritisoi Lönnrotin ehdotuksia jo sillä perusteella, että kielentutkimus oli osoittanut, että analyyttiset kielet olivat kehittyneempiä kuin synteettiset ja että Lönnrotin suosittelemat ilmaukset olisivat vieneet suomen kieltä kehityksessä pari sataa vuotta taaksepäin (Snellman 1848).

Snellmanin ja johtavien oikeakielisyysmiesten, Elias Lönnrotin ja myöhemmin August Ahlqvistin, sukset menivät niin pahasti ristiin, ettei Snellmanin ajatusta proosakielen esikuvallisuudesta otettu vakavasti ennen kuin E. N. Setälä palasi siihen virkaanastujaisesitelmässään vuonna 1893 (Setälä 1921: 144-147).

1870-luvun alussa astui esiin uusi fennomaanipolvi, jungfennomaanit, Yrjö Koskisen johdolla. Engman on kuvannut sitä, miten Koskinen otti haltuunsa kielitaistelun kannalta keskeisiä kulttuurilaitoksia, muun muassa Suomalaisen Kirjallisuuden Seuran sekä vuosina 1875 ja 1873 perustetut Suomen Historiallisen Seuran ja Kansanvalistusseuran (s. 123-126, 146). Se ei kuitenkaan tapahtunut helposti, sillä samaan aikaan fennomaanien johtajuutta tavoitteli myös August Ahlqvist, joka joutui kuitenkin sivuraiteelle. Engmanilta jää tässä yhteydessä mainitsematta, että kaikesta huolimatta Ahlqvist piti suomen kielen ohjailua tiukassa otteessaan. Hänellä oli siihen omat kanavansa, muun 
muassa Kieletär-niminen aikakauskirja. Lisäksi hän toimi Lönnrotin jälkeen suomen kielen professorina vuosina 18631888. Hän perusti myös vuonna 1876 "ylioppilasnuorisolle" tarkoitetun Kotikielen Seuran, joka toimii edelleen ja julkaisee suomen kielen tutkijoiden tärkeintä aikakauslehteä Virittäjää.

On merkille pantavaa, että koko suomalaisuusliikkeen ajan johtavat suomen kielen kehittäjät ja oikeakielisyysmiehet toimivat liikkeen ytimen ulkopuolella. Vasta E. N. Setälä oli ensimmäinen suomen kielen professori, joka osallistui näkyvästi myös (kieli)poliittiseen toimintaan, mutta hän ei puolestaan ollut millään tavoin mukana suomen kielen ohjailussa.

\section{Suomenruotsalaisuuden synty}

Suomenruotsalaisuuden synty nousee esille luvuissa "Mobilisointi" (s. 143-185) ja "Jakautuminen" (s. 186-249). Niissä tarkastellaan muun muassa Suomen kansan löytämistä 1810-luvulla ja ruotsalaisen rahvaan löytämistä 1850-1860-luvuilla. Puheeksi tulee myös koululaitoksen ja kansansivistystyön jakautuminen kielittäin. Merkittäviä mobilisaatiovaiheessa perustettuja suomenruotsalaisia instituutioita ovat Svenska litteratursällskapet i Finland ja vuonna 1906 perustettu Svenska Folkpartiet eli RKP.

Suomenruotsalaisuuden ytimeen päästään luvussa "Suomenruotsalaisuus" (s. 250-309). Aivan ensimmäiseksi Engman nostaa esiin sen, että ruotsista tuli vuonna 1809 plurisentrinen kieli. Aiemmin ruotsia oli puhuttu vain Ruotsin valtakunnan ydinalueilla, mutta vuodesta 1809 lähtien sitä on käytetty kahdessa maassa. Siihen on liittynyt ongelmia.

Suomenruotsalaisuuden kannalta keskeisiä seikkoja olivat kysymys omasta nimestä ja omasta kielestä. Kummastakin kehkeytyi vuosikymmenien mittainen kiistely, jossa esitettiin argumentteja eri näkemysten tueksi.
Nimikysymyksen keskiössä oli nimitys finländare, jota Engmanin mukaan oli käytetty jo keskiajalla ja usein 160o-luvulla mutta joka oli sitten jäänyt käytöstä. Esimerkiksi J. L. Runeberg käytti itsestään etnonyymiä finne. Vielä 1880-luvulle asti finländare-nimitystä käyttivät vain avoimesti ruotsinmieliset, mutta termi vakiintui tieteelliseen käyttöön 1890-luvulla. Kiistely siitä jatkui kuitenkin 1900-luvun alkupuolella, kunnes RKP asettui sen kannalle puoluekokouksessaan 1926. (S. 250-254.)

Toinen paljon keskustelua herättänyt kysymys oli Suomessa puhuttavan ruotsin suhde Ruotsissa puhuttavaan ruotsiin. Sitä ei suinkaan helpottanut se, että Suomessa puhuttiin hyvin monenlaista ruotsia esimerkiksi Pohjanmaan tai Uudenmaan rannikolla tai Helsingissä tai Viipurissa. Osa keskustelijoista, esimerkiksi C. G. Estlander, oli sitä mieltä, että suomenruotsille piti antaa liikkumatilaa kehittyä itsenäisesti. Lopullinen sana jäi kuitenkin suomenruotsin johtavalle normittajalle Hugo Bergrothille, joka lähti siitä, ettei suomenruotsi saisi etääntyä liiaksi ruotsinruotsista. Tämän periaatteen hän toi esiin tunnetuimmassa teoksessaan Finlandssvenska (1928 [1917]), johon hän myös kokosi joukon vältettäviä finlandismeja eli suomalaisuuksia. (S. 256-265.)

Suomenruotsalaisen puhekielen malliksi valittiin puolestaan Helsingin ruotsinkielisen sivistyneistön käyttämä kieli. Engmanin mukaan se merkitsi sitä, että "käytännössä noin kymmenen pääkaupunkilaiskorttelin asukkaat päättivät siitä, miten yhdeksän kymmenesosan maan ruotsinkielisestä väestöstä tuli puhua ja kirjoittaa, mikäli he halusivat liikkua oman sosiaaliryhmänsä ja kotiseutunsa ulkopuolella tai pitää yhteyttä sinne" (s. 263).

Engman viittaa myös siihen, että kansallisteatterit olivat eri puolilla Eurooppaa keskeinen osa kansakunnan rakentamista. Näyttämökielen tuli olla puhekielen mallina ja normittajana. (S. 265.) Helsingistä puuttui kuitenkin pitkään niin ruotsalai- 
nen kuin suomalainenkin teatteri. Ensimmäisenä näistä aloitti toimintansa ruotsinkielinen Nya Teatern vuonna 1860; sen nimi muuttui Svenska Teaterniksi vuonna 1887. Nimenmuutoksen taustalla oli kaupungissa vuonna 1872 toimintansa aloittanut Suomalainen Teatteri.

Ruotsalaisen Teatterin ongelmana oli alusta lähtien se, että valtaosa sen näyttelijöistä tuli Ruotsista ja puhui Tukholman puhekieltä, joka erosi monessa suhteessa Helsingin säätyläisten ruotsista. Niinpä helsinkiläiset eivät tunteneet teatteria omakseen. Svenska Teaternin tiloissa alettiinkin 1900-luvun alussa esittää näytelmiä myös kotimaisin voimin. Vuonna 1913 teatteriin perustettiin kaksi osastoa: ruotsinruotsalainen ja kotimainen osasto. Teatterilla ei kuitenkaan ollut varoja kahden linjan ylläpitämiseen, ja vuonna 1915 päätettiin jatkaa vain kotimaisen linjan toimintaa. Hugo Bergroth laati keväällä 1916 ohjeet teatterissa käytettävästä kielestä. Tuloksena oli kuitenkin se, että Erottajalla sijaitsevan Svenska Teaternin lavalla alettiin vähitellen käyttää sellaista kieltä, jota ei puhuttu missään muualla Helsingissä. Sitä alettiinkin ennen pitkää kutsua "skillnadskaksi", ja se säilyi Svenska Teaternin näyttämökielenä aina 1960-luvulle asti. (S. 265-271; Tandefelt 2019: 376-381.)

Samassa yhteydessä Engman mainitsee, että kun Suomalainen Teatteri perustettiin, "sen tie oli auki suoraan menestykseen" (s. 271). Mikään ei voisi olla kauempana totuudesta. Kun Suomalainen Teatteri aloitti toimintansa 1872, suomenkielistä sivistyneistöä oli Helsingissä vielä niin vähän, ettei sitä riittänyt kuin pariin kolmeen näytökseen kerrallaan. Teatteri joutuikin tekemään joka vuosi pitkiä kiertueita suomalaisella maaseudulla sekä Pietarissa, joka Kaarlo Bergbomin mukaan oli vuonna 1871 "suurin suomalainen kaupunki" (s. 61, 267).

Vielä suurempi ongelma oli Suomalaisessakin Teatterissa lavalla käytetty kieli.
Koska huomattava osa teatterin näyttelijöistä tuli ruotsinkielisistä perheistä, heidän suomen kielen taitonsa oli puutteellinen. Siitä kirjoitettiin usein sanoma- ja aikakauslehdissä, ensimmäisen kerran heti vuoden 1873 alussa. Vuonna 1885 asia tuli puheeksi myös Kotikielen Seurassa. Ruotsalainen vaikutus näkyi muun muassa siinä, että geminaattakonsonantit ja painottomat pitkät vokaalit ääntyivät usein lyhyinä, esimerkiksi heitää, kiitää, otta, anta pro heittää, kiittää, ottaa, antaa. E. N. Setälä kiinnitti lisäksi huomiota naisnäyttelijöiden puheessa esiintyvään epäsuomalaisen terävään s:ään. (Paunonen 1976: 337.)

Vielä 1900-luvun alkupuolella Kansallisteatterin näyttelijöiden kielessä oli paljon puutteita. Viljo Tarkiainen kirjoitti niistä kriittisessä katsauksessaan vuonna 1913. Näkyvimpiä oli naisnäyttelijöiden kielessä edelleen yleinen, "terävästi ja pitkästi” ääntyvä $s$, joka sai repliikit "soimaan miltei pelkältä sihinältä". (Tarkiainen 1913: 154-155.) Suomenruotsin $s$ on muutenkin etisempi kuin suomen $s$, mutta kvantiteetiltaan pitkä, etinen $s$ oli alkuaan peräisin Helsingin ruotsinkielisen yläluokan puheesta, missä soinnittomat konsonantit $p$, $t, k$ ja $s$ ääntyvät tietyissä asemissa pitkinä. Mikael Reuterin ja Therese Leinosen mukaan kyseessä on edelleenkin hyvin selvä sosiaalinen markkeri, johon on liittynyt vahva prestiisi. (Reuter 2014: 50; 2015: 25, 28; Leinonen 2015: 39. $)^{1}$

Olennaista on, että maamme kummankin päänäyttämön lavalla on pitkään puhuttu sellaista ruotsia ja suomea, jotka ovat olleet kaukana Helsingin ruotsinja suomenkielisen sivistyneistön käyttämästä kielestä tai kielellisistä ihanteista.

Suomi ja ruotsi ovat kohdanneet Helsingissä niin säätyläisten kuin työläistenkin keskuudessa. Engman on tarkastellut myös Helsingin työläiskaupunginosia ja

1. Naisnäyttelijöiden "terävästä" s:stä Paunonen 1980: 20-22; 2006: 46-47 sekä laajemmin Halonen, Nyström, Paunonen \& Vaattovaara tulossa. 
niiden esperantoa eli vanhaa Stadin slangia (s. 286-289). Hän on ajoittanut sen synnyn 189o-luvulle, mutta nykytietojen valossa kyseessä on ainakin 20 vuotta vanhempi kieli. Vanhentuneisiin lähteisiin perustuu myös hänen mainintansa siitä, että venäläisperäisiä sanoja olisi vanhassa slangissa ollut noin sata. Todellisuudessa niitä on ollut noin 350 (Paunonen 2016: 68).

Vanhan slangin äännejärjestelmästä Engman toteaa, että se oli ainutlaatuinen yhdistelmä ruotsia ja suomea. Ruotsalaisperäisinä äänteinä hän mainitsee soinnilliset klusiilit $(b, d, g)$ sekä frikatiivin $f$. Jostain syystä hän ei ole noteerannut kahta suhusibilanttia ( $̌$ ja $t \grave{s})$, jotka ovat aikanaan antaneet vanhalle slangille sille ominaisen "suhahtavan" tai "suhisevan" sävyn; tähän lehdissäkin 1900-luvun alussa viitattiin, esimerkiksi šingraa 'lähteä pois, häipyä, tšiikaa, tšiigaa 'katsoa', mutši 'äiti'. Nämä suhusibilantit olivat peräisin ruotsista ja osin venäläisperäisistäkin lainasanoista.

Helsingin suomeen on näin lainattu Helsingin ruotsista kolme sibilanttifoneemia. Etinen, terävän sihahtava ja usein pitkänä ääntynyt /s/ oli lähtöisin Helsingin ruotsinkielisen yläluokan puheesta, ja varhaisimmat tiedot siitä ovat peräisin Suomalaisen Teatterin naisnäyttelijöiden kielestä. Kaksi suhusibilanttia /š/ ja /tš/ ovat kuuluneet slangia puhuneiden työläispoikien ja nuorten miesten kieleen.

Engman käsittelee myös kielirajaa sekä suomenkielisten alueiden sisälle jääviä "kielisaarekkeita", joita ovat olleet muiden muassa Viipuri, Kotka, Pori, Oulu, Tampere (sisämaan suurin kielisaareke) sekä Kuopio ja Raahe (s. 280-282). Myös Pietarin suomen- ja ruotsinkieliset tulevat monessa kohdin puheeksi.

\section{Vastakkainasettelusta tasa-arvoiseen tasavaltaan}

Teoksen päättää kaksi lukua, joista ensimmäinen, "Politiikka Ruotsalaisessa Suomessa" (s. 310-361), käsittelee muun muassa suomenruotsalaista kielipolitiikkaa sekä suomenruotsalaisten puolueiden ja ryhmäkuntien järjestäytymistä. $\mathrm{Pu}$ heeksi tulevat A. O. Freudenthalin johtamat Viikingit sekä RKP. Engman nostaa esiin myös 190o-luvun alkupuolella ruotsalaisen ja suomalaisen rodun ominaispiirteistä ja paremmuudesta käydyt rasistiset riidat (s. 346-352). Jälkimmäisessä luvussa "Tasavalta" (s. 362-414) tarkastellaan Ruotsin suhtautumista Suomen sisällissotaan, Ahvenanmaan kysymystä sekä itsenäisen Suomen hallitusmuotoa ja kielilakeja, joiden yhteydessä erityisesti E.N. Setälän osuus nostetaan esiin. Lopuksi puhutaan vielä Suomenruotsalaisista kansankäräjistä, joista päätettiin 1919.

Kaikkiaan Engmanin teos on valtava tietopaketti kaikille suomen ja ruotsin kielestä kiinnostuneille. Teos on myös itse ylittänyt kielirajan: ensimmäistä kertaa tarkastellaan samojen kansien sisällä näin perusteellisesti sekä suomalaisuusliikettä että suomenruotsalaisuuden syntyä ja kehittymistä. Viittasin jo siihen, että monessa kohtaa lukija huomaa, että nämä kaksi ilmiötä ovat toistensa peilikuvia, tosin usein vuosikymmenien viiveellä. Autonomian aikana erilaisten valintojen eteen joutunut Suomi selvisi suuren keisarikunnan osana ehjin nahoin, eikä 180o-luvun lopulla ja 1900-luvun alussa kiihkeäksi yltynyt kielitaistelukaan lopulta hajottanut kansakuntaa.

Heikki Paunonen etunimi.sukunimi@kolumbus.fi

Kirjoittaja on Tampereen yliopiston suomen kielen emeritusprofessori ja Helsingin yliopiston suomen kielen dosentti.

\section{Lähteet}

Bergroth, Hugo 1928 [1917]: Finlandssvenska. Handledning till undvikande av provinsialismer $i$ tal och skrift. Toinen, uudistettu laitos. Helsingfors: Författa- 
rens förlag.

Halonen, Mia - Nyström, Samu -

Paunonen, Heikki - VaAtTovaAra, JOHANNA (tekeillä): Stadin syntinen s. Käsikirjoitus.

LeinOnen, Therese 2015: Exempel på variation och förändring i större städers språk. - Marika Tandefelt (toim.), Gruppspråk, samspråk, två språk. Svenskan $i$ Finland - $i$ dag och $i$ går I:2 s. 35-46. Helsingfors: Svenska litteratursällskapet.

LÖnnRot, Elias 1845: Muukalaisuudesta Suomessa. - Suomi. Tidskrift i fosterländska ämnen 1844 s. 159-184. Helsingfors: Finska-Litteratur-Sällskapets förlag.

Paunonen, Heik i 1976: Kotikielen Seura 1876-1976. - Virittäjä 8o s. 310-432.

— 1980: Finskan i Helsingfors. - Helsingfors två språk. Rapport I s. 5-41. Meddelanden från institutionen för nordiska språk och nordisk litteratur vid Helsingfors universitet. Serie B nr 4. Helsingfors: [Helsingfors universitet].

_ 2006: Vähemmistökielestä varioivaksi valtakieleksi. - Kaisu Juusela \& Katariina Nisula (toim.), Helsinki kieliyhteisönä s. 13-99. Suomen kielen ja kotimaisen kirjallisuuden laitos. Helsinki: Helsingin yliopisto. 2016: Sloboa Stadissa. Stadin slangin etymologiaa. Jyväskylä: Docendo.

Reuter, Mikael 2014: Så här ska det låta. Om finlandssvenska och språkriktighet. Vasa: Scriptum.

_ 2015: Finlandssvenskt uttal. - Marika Tandefelt (toim.), Gruppspråk, samspråk, två språk. Svenskan i Finland - i dag och i går I:2 s. 19-34. Helsingfors: Svenska litteratursällskapet.

Setälä, E. N. 1921: Kielentutkimus ja oikeakielisyys. Helsinki: Kustannusyhtiö Otava.

SNEllman, J. V. 1845: Om finska språket såsom skriftspråk. - Saima 31.1.1845.

_ 1848: Finnes en Finsk Prosa? - Litteraturblad 12 s. 376-382.

Tandefelt, Marika 2019: Finlandssvenska på scenen i hundra år. - Marika Tandefelt (toim.), Finländsk svenska från 1860 till nutid. Svenskan i Finland - i dag och $i$ går III:2 s. 375-413. Helsingfors: Svenska litteratursällskapet.

Tarkiainen, Viljo 1913: Suomenkielen lausumisesta näyttämöillämme. - Näyttämötaide 8 s. 153-158.

\section{Karjalaan suostuneita}

\section{Marja Torikka \& Jaakko Yli-Paavola} (toim.): Täyttä työtä. Akateemikko Pertti Virtarannan satavuotismuisto. Helsinki: Karjalan Sivistysseura 2018. 294 s. ISBN 978952-7193-16-7.

Kaikista työssään ansioituneista ei tehdä muistokirjaa, mutta Pertti Virtarannan kollegoiden, alaisten ja moninaisten matkatovereiden mielestä sellainen oli akateemikko Virtarannasta välttämätön. Marja Torikan ja Jaakko Yli-Paavolan toimittamaan satavuotismuistokirjaan Täyttä työtä on kirjoittanut kaikkiaan 12 henkilöä. Kirjan toimittajat ovat päivänneet teoksen al- kusanat Pertti Virtarannan syntymän satavuotispäivänä 20. toukokuuta 2018.

Teos alkaa Virtarannan lapsuuden koulutien maisemista ja loppuu hänen viimeisiin käynteihinsä itärajan takana. Aiheita riittää karjalan murteiden ja ruotsin- ja amerikansuomen tallentamisesta nauhoitearkiston ja UKANin eli ulkomaanlehtori- ja kielikurssiasiain neuvottelukunnan perustamiseen. Tietoa saadaan myös Virtarannan vaiheikkaista matkoista kielisukulaisten luo sekä perhearjesta ja kesien vietosta. Teoksen kirjoittamiseen on osallistunut varsinaisten kirjoittajien lisäksi myös Helmi Virta- 